\title{
NUMERICAL AND EXPERIMENTAL ANALYSIS OF DIVIDING FLOW IN SHORT OPEN CHANNEL TRIBUTARIES
}

\author{
Ali, N.A., \\ Prof. of Hydraulics, Civil Eng. Dept., Assiut University, Assiut, 71516 Egypt \\ Gamal Abozeid, \\ Associate Prof., Civil Eng. Dept., Assiut University, Assiut, 71516 Egypt
}

Kamal A.M., and

Lecturer, Civil Eng. Dept., Aswan University, Egypt

Khaled M.A.

Ass. Lect., Civil Eng. Dept., Aswan University, Egypt

(Received March 10, 2007 Accepted September 3, 2007)

Dividing flow in open channel junction is of interest in environmental and hydraulic engineering. It occurs in many hydraulic structures ranging from wastewater treatment facilities to fish passage conveyance structures, irrigation and drainage canals and natural river system. In this research, Schwarz-Christoffel transformation and principle of energy are used to predict the flow rates, the flow depths and values of Froude number in the tributary channels of rectangular open channel junction with three tributary channels. Also, an experimental program is performed to verify the numerical results of the theoretical solutions. The difficulty of a theoretical study of the dividing flow in an open channel due to the flow separation, recirculation regions and possibility of formation of hydraulic jump makes the complete numerical analysis of the problem impossible. However, in this study, with some particular assumptions to the problem, by adopting the conformal mapping technique (SchwarzChristoffel transformation theory) and by applying the principle of conservation of energy, the flow pattern at a rectangular junction with three tributary channels is simulated; the numerical model is programmed on the computer with MATLAB Version 6.0.0.88 and the flow characteristics are evaluated. The verification of the results of the numerical model shows a will agreement between these results and those from the experimental model. The results revealed that: 1) Froude number in the main channel has negligible influence on the flow rates in the branches. 2) Flow characteristics in the main channel extension or in the branches depend largely on the geometrical dimensions of the junction. 3) The relative depths in the tributary channels independent of the junction geometry.

KEYWORDS: Open channel Junction, Schwarz-Christoffel Transformation, Dividing Flow. 


\section{NOMENCLATOR}

The following symbols are used in this paper:

a, b, c, d, Real unknown parameters

$\mathrm{j}, \mathrm{f}$ and $\mathrm{h}$ depending on junction

$\begin{array}{ll} & \text { geometry } \\ B_{S} & \text { width of the channel }\end{array}$

$F_{S} \quad$ Froude number in a channel

$G \quad$ Acceleration of gravity

$N \quad$ Complex constant

$N \quad$ Subscript for Z-plane and $\lambda-$ plane

$Q$ and $Q_{S} \quad$ Flow rates in upstream main

channel and in a tributary

channel respectively.

$U_{S} \quad$ Mean velocity in a channel

$W_{S} \quad$ Relative width of a channel

$X_{S} \quad$ Relative flow depth

$Z_{n}$ Complex position in physical plane $=x_{n}+y_{n}$

$\omega \quad$ Complex potential $=\Phi+\mathrm{i} \psi$

$\Psi \quad$ Stream function

$\theta_{1}$ first angle of intersection at the junction.

$\theta_{2}$ second angle of intersection at the junction.

$\Phi \quad$ Velocity potential

$\lambda_{n} \quad$ Transformation plane $=\xi_{\mathrm{n}}+\mathrm{i} \eta_{\mathrm{n}}$

$\omega$ Complex potential $=\Phi+\mathrm{i} \psi$

Subscript $s=$ in any of the quantities $\mathrm{W}_{\mathrm{S}}, X_{S}, Q_{S}, U_{S}, Y_{S}, F_{S}$ and $B_{S}$ when no sub-s is used, the symbol refers to the upstream main-channel

When $s=1$, the symbol refers to the main channel extension.

When $s=2$ or 3 , the symbol refers to the branch of angle $\theta_{1}$ or $\theta_{2}$ respectively.

\section{INTRODUCTION}

For a specific dividing flow (T-junction), Taylor [1] carried out the first experiments on the problem. He suggested graphical representation in terms of discharges ratio and depths ratio. Neary and Odgaard [2] investigated the flow structure at $90^{\circ}$ open channel diversion. From the velocity data, they [2] concluded that the flow at open channel diversion is a three-dimensional flow. Dividing flow in open channel junction generated theoretical interest due to a number of important flow phenomena involved. Detailed hydrodynamics of junction flow are found to be complex and there exist a number of parameters that characterizes the flow physics. This includes the size, shape, slope, angles between the dividing channels and the flow Reynolds and Froude numbers. Thereby, many investigators [1-13] studied this problem to stand on the main factors affecting this problem and determine the practical solutions. After investigating the flow at $90^{\circ}$ open channel junction, Hsu [6] concluded that the energy heads upstream and downstream of the diversion almost be equal. After heir study on $90^{\circ}$ open channel junction, Law and Reynolds [9] concluded that, at high Froude number $(\mathrm{F}>0.7)$ both the energy and momentum theories are inaccurate. Rashwan [11] developed a one-dimensional theoretical model for sub-critical flow in dividing open channel junction. He applied the momentum principles in the stream-wise direction to two control volumes in the junction. This allows the model to be easily implemented in network models [11].

The conformal mapping approach was first adopted for the problem of channel junctions with combining flow by Greated [5]. By using the Schwarz-Christoffel 
transformation, he developed expression for locating the stagnation point for rectangular channel with 90 junction angle. Webber and Greated [12] began the focus on the general flow characteristics at an open-channel junction. Using conformal mapping, they were able to locate the stagnation point at the upstream corner of the channel junction and delineate the zone of separation. They also included a method for estimating the relative energy loss across the junction. Ali [3] applied the SchwarzChristoffel transformation theory and the principle of conservation of energy to twodimensional numerical model consists of main channel divided to one branch channel plus the extension of the main channel. Ali and Gommah [4] succeeded for the second time to apply the same previous technique plus super-position technique according to Milne-Thomson [15] to evaluate the flow characteristics at open channel junction. Hassenpflug [7] had derived equations of free-streamline flow of a branched channel in plane incompressible flow using the hodograph method combined with Blasius-Prandtl method. He [7] also gave correct results of Modi et al. [10] and Sinha and Odgaard. [14].

This research aims to investigate numerically and experimentally the influence of both the junction geometry and flow type in the main channel on the divided flow characteristics in the tributary channels.

\section{SIMULATION OF THE NUMERICAL MODEL}

Assumption: Figure (1-a) shows the junction geometry considered as an extension of the main channel. The main assumptions in this analysis are: 1) The channel junction is in rectangular shape with horizontal smooth bed. 2) The flow is irrotational and subcritical. 3) The flow velocity in the branch channels is uniform irrespective of the reverse influence of the tributaries on the velocity distribution in the main extension. 4) The loss of energy in the short junction is negligible.

Theory: In order to obtain a general solution of the problem, the various boundaries of a channel junction, as represented in the $Z$-plane $(Z=x+i y)$ as shown in Fig. (1-a) must be transformed to the real axis of a $\lambda$-plane $(\lambda=\xi+i \eta)$ as shown in Fig. (1-b), the points within the region of flow between the boundaries are transformed to the corresponding points in the upper half of the $\lambda$-plane $(\lambda=\xi+i \eta)$. By using the theorem of Schwarz-Christoffel, the corresponding expression for the transformation is as follows [15]:

$\mathrm{dZ} / \mathrm{d} \lambda=\mathrm{N}(\lambda-\mathrm{b})^{\left(\theta_{2} / \pi\right)}(\lambda-\mathrm{d})^{\left(1-\theta_{2} / \pi\right)}(\lambda-\mathrm{j})^{\left(1-\theta_{1} / \pi\right)}(\lambda-\mathrm{a})^{(-1)}(\lambda-\mathrm{f})^{(-1)}(\lambda-\mathrm{h})^{(-1)}(\lambda-\mathrm{c})^{(-1)} \ldots \ldots \ldots$

where $\mathrm{N}$ is a complex number, $\mathrm{b}, \mathrm{d}, \mathrm{j}, \mathrm{a}, \mathrm{f}, \mathrm{h}$ and $\mathrm{c}$ are real unknown parameters determined from the geometric dimensions of the junction, and $\theta_{1}$ and $\theta_{2}$ are the junction angles.

Determination of Subsidiary Parameters: Schwarz-Christoffel transform-ation involves unknown parameters, which must be determined before the mapping, can be applied to the physical problem. All the previous works determined these parameters using various integration methods along the real axis of the $\lambda$ plane, together with some form of iterative procedure. Some examples of such methods are presented in [3,4,7,10,15,16-18]. Milne-Thomson [15] gave analytic solution by using a hodograph 
method, Modi et al. [10], Ali [3] and Ali and Gommah [4] have used conventional Schwarz-Christoffel transformation to map walls on a straight line. They obtained analytically the mapping of the corner points
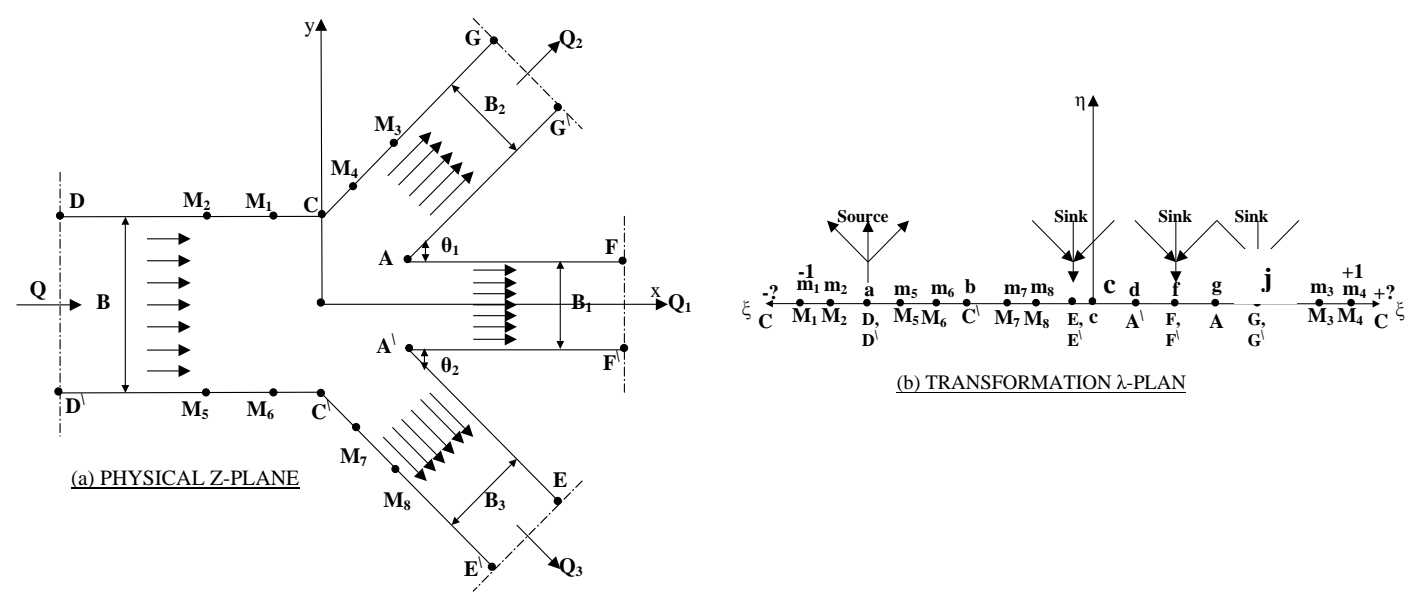

Fig. (1) Definition sketch Physical and Transformation planes

Chaung et al. [16] integrated along the real axis in the $\lambda$ plane to determine the lengths of all sides, and applied Kantorovich and Krylov [19] method to evaluate the singular integrations by separating the improper integral into two parts, namely a finite form in a continuous region which can be integrated exactly and a definite integral which is free of any singularity. The Gauss-Jacobi quadrature was used to evaluate these integrals. The most used iterative procedure is the Newton-Raphson method, with the Jacobian matrix approximated by a finite difference quotient matrix, as applied to branched channels by Hassenpfug [7]. Trevelyan et al. [18] had used an alternative integration approach from that employed by Hassenpflug [7] in the iterative mathematical technique for determining the parameters involved in the SchwarzChristoffel transformation

Numerical solutions are also available by using standard programs SCPACK by Trefethen [20], or Algorithm 756 of MATLAB by Driscoll [21] who compute points in the physical plane by numerical integration of the Schwarz-Christoffel integral. In this research, the Algorithm 756 of MATLAB by Driscoll [21] is used to find the unknown parameters.

Discharge and Flow Depth: In the transformation plan ( $\lambda$-plane), if a source at point D (Fig.1-a) of strength ( $\mathrm{UB} / \pi)$ and three sinks at points $F, G$ and $E$ of strength $\left(\mathrm{U}_{1} \mathrm{~B}_{1} / \pi\right),\left(\mathrm{U}_{2} \mathrm{~B}_{2} / \pi\right)$ and $\left(\mathrm{U}_{3} \mathrm{~B}_{3} / \pi\right)$ respectively, the complex potential in ( $\lambda$-plane) may be given by:

$$
\begin{aligned}
& \omega=\left(-\mathrm{UB}^{*} \ln (\lambda-\mathrm{a})\right) / \pi+\left(\mathrm{U}_{1} \mathrm{~B}_{1} * \ln (\lambda-\mathrm{f})\right) / \pi+\left(\mathrm{U}_{2} \mathrm{~B}_{2} * \ln (\lambda-\mathrm{h})\right) / \pi+
\end{aligned}
$$

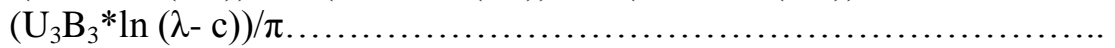

$$
\begin{aligned}
& \mathrm{d} \omega / \mathrm{d} \lambda=\left(-\mathrm{UB} /(\pi(\lambda-\mathrm{a}))+\left(\mathrm{U}_{1} \mathrm{~B}_{1} / \pi(\lambda-\mathrm{f})\right)+\left(\mathrm{U}_{2} \mathrm{~B}_{2} / \pi(\lambda-\mathrm{h})\right)+\left(\mathrm{U}_{3} \mathrm{~B}_{3} / \pi(\lambda-\mathrm{c}) \ldots\right.\right.
\end{aligned}
$$

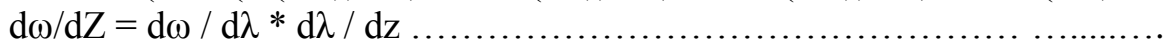


With the substitution from Eqns. (1 and 3) into Eqn. (4) that is:

$$
\begin{aligned}
\mathrm{d} \omega / \mathrm{dz}= & \left(-\mathrm{UB}(\lambda-\mathrm{c})(\lambda-\mathrm{f})(\lambda-\mathrm{h})+\mathrm{U}_{1} \mathrm{~B}_{1}(\lambda-\mathrm{a})(\lambda-\mathrm{c})(\lambda-\mathrm{h})+\mathrm{U}_{2} \mathrm{~B}_{2}(\lambda-\mathrm{a})(\lambda-\mathrm{c})(\lambda-\mathrm{f})+\mathrm{U}_{3} \mathrm{~B}_{3}(\lambda-\mathrm{a})(\lambda-\right. \\
& \mathrm{f})(\lambda-\mathrm{h})) *\left(1 /\left(\pi \mathrm{N}(\lambda-\mathrm{b})^{\left(\theta_{2} / \pi\right)}(\lambda-\mathrm{d})^{\left(1-\theta_{2} / \pi\right)}(\lambda-\mathrm{j})^{\left(1-\theta_{1} / \pi\right)}\right)\right) \ldots \ldots \ldots \ldots \ldots
\end{aligned}
$$

At the stagnation points $\mathrm{A}$ and $\mathrm{A}^{\prime}$ in Fig. (1)

$\mathrm{d} \omega / \mathrm{dz}=0, \lambda=\mathrm{j}$ and $\mathrm{d} \omega / \mathrm{dz}=0, \lambda=\mathrm{d}$ respectively, so Eqn. (5) becomes:

$(-\mathrm{UB} /(\mathrm{j}-\mathrm{a}))+\left(\mathrm{U}_{1} \mathrm{~B}_{1} /(\mathrm{j}-\mathrm{f})\right)+\left(\mathrm{U}_{2} \mathrm{~B}_{2} /(\mathrm{j}-\mathrm{h})\right)+\left(\mathrm{U}_{3} \mathrm{~B}_{3} /(\mathrm{j}-\mathrm{c})\right)=0$.

$(-\mathrm{UB} /(\mathrm{d}-\mathrm{a}))+\left(\mathrm{U}_{1} \mathrm{~B}_{1} /(\mathrm{d}-\mathrm{f})\right)+\left(\mathrm{U}_{2} \mathrm{~B}_{2} /(\mathrm{d}-\mathrm{h})\right)+\left(\mathrm{U}_{3} \mathrm{~B}_{3} /(\mathrm{d}-\mathrm{c})\right)=0$

For dimensionless form let us consider:

$\mathrm{K}=$ Relative velocity. $\mathrm{K}_{1}=\mathrm{U}_{1} / \mathrm{U}, \mathrm{K}_{2}=\mathrm{U}_{2} / \mathrm{U}$ and $\mathrm{K}_{3}=\mathrm{U}_{3} / \mathrm{U}$

$\mathrm{W}=$ relative width. $\mathrm{W}_{1}=\mathrm{B}_{1} / \mathrm{B}, \mathrm{W}_{2}=\mathrm{B}_{2} / \mathrm{B}$ and $\mathrm{W}_{3}=\mathrm{B}_{3} / \mathrm{B}$

So Eqns. (6 and 7) may be re- written as:

$\left(\mathrm{K}_{1} \mathrm{~W}_{1} /(\mathrm{j}-\mathrm{f})\right)+\left(\mathrm{K}_{2} \mathrm{~W}_{2} /(\mathrm{j}-\mathrm{h})\right)+\left(\mathrm{K}_{3} \mathrm{~W}_{3} /(\mathrm{j}-\mathrm{c})\right)+(-1 /(\mathrm{j}-\mathrm{a}))=0$.

$\mathrm{K}_{2}=\left((1 /(\mathrm{j}-\mathrm{a}))-\left(\mathrm{K}_{1} \mathrm{~W}_{1} /(\mathrm{j}-\mathrm{f})\right)-\left(\mathrm{K}_{3} \mathrm{~W}_{3} /(\mathrm{j}-\mathrm{c})\right)\right)^{*}\left((\mathrm{j}-\mathrm{h}) / \mathrm{W}_{2}\right) \ldots$

$\left(\mathrm{K}_{1} \mathrm{~W}_{1} /(\mathrm{d}-\mathrm{f})\right)+\left(\mathrm{K}_{2} \mathrm{~W}_{2} /(\mathrm{d}-\mathrm{h})\right)+\left(\mathrm{K}_{3} \mathrm{~W}_{3} /(\mathrm{d}-\mathrm{c})\right)+(-1 /(\mathrm{d}-\mathrm{a}))=0$.

$\mathrm{K}_{3}=\left((1 /(\mathrm{d}-\mathrm{a}))-\left(\mathrm{K}_{1} \mathrm{~W}_{1} /(\mathrm{d}-\mathrm{f})\right)-\left(\mathrm{K}_{2} \mathrm{~W}_{2} /(\mathrm{d}-\mathrm{h})\right)\right) *\left((\mathrm{~d}-\mathrm{c}) / \mathrm{W}_{3}\right)$.

By the substitution from Eqn. (11) into Eqn. (8), one has;

$\mathrm{K}_{2} \mathrm{~W}_{2}((1 /(\mathrm{j}-\mathrm{h}))-((\mathrm{d}-\mathrm{c}) /((\mathrm{d}-\mathrm{h}) *(\mathrm{j}-\mathrm{c}))))+\mathrm{K}_{1} \mathrm{~W}_{1}((1 /(\mathrm{j}-\mathrm{f}))-((\mathrm{d}-\mathrm{c}) /((\mathrm{j}-\mathrm{c}) *(\mathrm{~d}-\mathrm{f}))))-$ $((1 /(\mathrm{j}-\mathrm{a}))-((\mathrm{d}-\mathrm{c}) /((\mathrm{d}-\mathrm{a}) *(\mathrm{j}-\mathrm{c}))))=0$.

$\mathrm{K}_{2} \mathrm{~W}_{2} \mathrm{C}_{1}+\mathrm{K}_{1} \mathrm{~W}_{1} \mathrm{C}_{2}-\mathrm{C}_{3}=0$

$\mathrm{K}_{2}=\left(\mathrm{C}_{3}-\mathrm{K}_{1} \mathrm{~W}_{1} \mathrm{C}_{2}\right) /\left(\mathrm{W}_{2} \mathrm{C}_{1}\right)$

where;

$\mathrm{C}_{1}=((1 /(\mathrm{j}-\mathrm{h}))-((\mathrm{d}-\mathrm{c}) /((\mathrm{d}-\mathrm{h}) *(\mathrm{j}-\mathrm{c}))))$

$\mathrm{C}_{2}=\left((1 /(\mathrm{j}-\mathrm{f}))-\left((\mathrm{d}-\mathrm{c}) /\left((\mathrm{j}-\mathrm{c})^{*}(\mathrm{~d}-\mathrm{f})\right)\right)\right)$

$\mathrm{C}_{3}=((1 /(\mathrm{j}-\mathrm{a}))-((\mathrm{d}-\mathrm{c}) /((\mathrm{d}-\mathrm{a}) *(\mathrm{j}-\mathrm{c}))))$

Substitution from Eqn. (9) into Eqn. (10), it yields

$\mathrm{K}_{1} \mathrm{~W}_{1}\left((1 /(\mathrm{d}-\mathrm{f}))-\left((\mathrm{j}-\mathrm{h}) /\left((\mathrm{j}-\mathrm{a})^{*}(\mathrm{~d}-\mathrm{h})\right)\right)\right)+\mathrm{K}_{3} \mathrm{~W}_{3}\left((1 /(\mathrm{d}-\mathrm{c}))-\left((\mathrm{j}-\mathrm{h}) /\left((\mathrm{j}-\mathrm{c})^{*}(\mathrm{~d}-\mathrm{h})\right)\right)\right)-$ $((1 /(d-a))-((j-h) /((j-a) *(d-h))))=0$

$\mathrm{K}_{1} \mathrm{~W}_{1} \mathrm{C}_{4}+\mathrm{K}_{3} \mathrm{~W}_{3} \mathrm{C}_{5}-\mathrm{C}_{6}=0$.

$\mathrm{K}_{3}=\left(\mathrm{C}_{6}-\mathrm{K}_{1} \mathrm{~W}_{1} \mathrm{C}_{4}\right) /\left(\mathrm{W}_{3} \mathrm{C}_{5}\right)$.

Where;

$\mathrm{C}_{4}=((1 /(\mathrm{d}-\mathrm{f}))-((\mathrm{j}-\mathrm{h}) /((\mathrm{j}-\mathrm{a}) *(\mathrm{~d}-\mathrm{h}))))$

$\mathrm{C}_{5}=\left((1 /(\mathrm{d}-\mathrm{c}))-\left((\mathrm{j}-\mathrm{h}) /\left((\mathrm{j}-\mathrm{c})^{*}(\mathrm{~d}-\mathrm{h})\right)\right)\right)$

$\mathrm{C}_{6}=\left((1 /(\mathrm{d}-\mathrm{a}))-\left((\mathrm{j}-\mathrm{h}) /\left((\mathrm{j}-\mathrm{a})^{*}(\mathrm{~d}-\mathrm{h})\right)\right)\right)$

In this simulation, the flow in the junction is assumed to be subcritical flow ( $F$ $\leq 0.7)$ and the energy loss due to the formation of eddies or the flow deflection or both is disregarded. Therefore, the application of energy conservation in the main and the diverging branches gives:

$\mathrm{Y}+\mathrm{U}^{2} / 2 \mathrm{~g}=\mathrm{Y}_{1}+\mathrm{U}_{1}^{2} / 2 \mathrm{~g}$

$\mathrm{Y}+\mathrm{U}^{2} / 2 \mathrm{~g}=\mathrm{Y}_{2}+\mathrm{U}_{2}^{2} / 2 \mathrm{~g}$

$\mathrm{Y}+\mathrm{U}^{2} / 2 \mathrm{~g}=\mathrm{Y}_{3}+\mathrm{U}_{3}^{2} / 2 \mathrm{~g}$ 
In the dimensionless form, Eqns. (20, 21 and 22) may be rearranged as:

$\mathrm{X}_{1}=1+0.5 \mathrm{~F}^{2}\left(1-\mathrm{K}_{1}^{2}\right)$

$\mathrm{X}_{2}=1+0.5 \mathrm{~F}^{2}\left(1-\mathrm{K}_{2}^{2}\right)$

$\mathrm{X}_{3}=1+0.5 \mathrm{~F}^{2}\left(1-\mathrm{K}_{3}^{2}\right)$

$\mathrm{Q}=\mathrm{Q}_{1}+\mathrm{Q}_{2}+\mathrm{Q}_{3}$

$\mathrm{UBY}=\mathrm{U}_{1} \mathrm{~B}_{1} \mathrm{Y}_{1}+\mathrm{U}_{2} \mathrm{~B}_{2} \mathrm{Y}_{2}+\mathrm{U}_{3} \mathrm{~B}_{3} \mathrm{Y}_{3}$

In dimensionless form Eqn. (27) becomes;

$\mathrm{K}_{1} \mathrm{~W}_{1} \mathrm{X}_{1}+\mathrm{K}_{2} \mathrm{~W}_{2} \mathrm{X}_{2}+\mathrm{K}_{3} \mathrm{~W}_{3} \mathrm{X}_{3}=1$

By substitution from Eqns. (14, 18, 23, 24 and 25) into Eqn. (28) one have;

$\mathrm{K}_{1} \mathrm{~W}_{1}\left(1+0.5 \mathrm{~F}^{2}\left(1-\mathrm{K}_{1}^{2}\right)\right)+\left(\left(\mathrm{C}_{3}-\mathrm{K}_{1} \mathrm{~W}_{1} \mathrm{C}_{2}\right) / \mathrm{C}_{1}\right) *\left(1-0.5 \mathrm{~F}^{2}\right.$

$\left.\left(1-\left(\left(\mathrm{C}_{3}-\mathrm{K}_{1} \mathrm{~W}_{1} \mathrm{C}_{2}\right) / \mathrm{W}_{2} \mathrm{C}_{1}\right)^{2}\right)\right)+\left(\left(\mathrm{C}_{6}-\mathrm{K}_{1} \mathrm{~W}_{1} \mathrm{C}_{4}\right) / \mathrm{C}_{5}\right)^{*}$

$\left(1-\left(1+0.5 \mathrm{~F}^{2}\left(1-\left(\left(\mathrm{C}_{6}-\mathrm{K}_{1} \mathrm{~W}_{1} \mathrm{C}_{4}\right) / \mathrm{W}_{3} \mathrm{C}_{5}\right)^{2}\right)\right)=1\right.$

For the known values of $\mathrm{F}, \mathrm{W}_{1}, \mathrm{~W}_{2}$ and $\mathrm{W}_{3}$, Eqn. (29) is solved by MATLAB function for finding the roots to determine the values of $\mathrm{K}_{1}$. Thereafter, the values of $\mathrm{K}_{2}, \mathrm{~K}_{3}$ are obtained from Eqns.(14) and (18) respectively. Then the relative depths $\mathrm{X}_{1}$, $X_{2}$ and $X_{3}$ are found from Eqns. (23, 24 and 25).

Computer Facility: Flow chart of the main program; A MATLAB Version 6.0.0.88 program was written for digital computer. Shown in Fig (2) is the flow chart, which explains, the essential features of this program.

Range of variable parameters: Intersection angles $\theta_{1}$ and $\theta_{2}$ varied to take $90^{\circ}$, $60^{\circ}$ and $30^{\circ}$ for each, relative widths of the branched channels $\mathrm{W}_{1}, \mathrm{~W}_{2}$ and $\mathrm{W}_{3}$ varied from 1 to 0.3 with step 0.1 for each and Froude number in the main channel, $F$ varies from 0.0 to 0.7 with step 0.1 .

Input data: Intersection angles $\theta_{1}$ and $\theta_{2}$, relative widths of the branched channels $\mathrm{W}_{1}$, $\mathrm{W}_{2}$, and $\mathrm{W}_{3 .}$ and Froude number in the main channel, $\mathrm{F}$.

Output data: The following outputs may be taken from the program: Froude numbers in tributary channels, $F_{1}, F_{2}$ and $F_{3}$. The relative flow depths $Y_{1} / Y, Y_{2} / Y$ and $Y_{3} / Y$. The relative flow rates $\mathrm{Q}_{1} / \mathrm{Q}, \mathrm{Q}_{2} / \mathrm{Q}$ and $\mathrm{Q}_{3} / \mathrm{Q}$.

\section{EXPERIMENTAL WORK AND PROCEDURE}

The experimental tests were executed in small, horizontal, rectangular channels. The channels were made of wood. The main channel and its extension have constant width of $200 \mathrm{~mm}$ and total length of $4.00 \mathrm{~m}$. The widths of the branches were changed to take 100,150 and $200 \mathrm{~mm}$ while their lengths were constant at $2.00 \mathrm{~m}$. The intersection of the branches with the main channel was located at $2.00 \mathrm{~m}$ from its entrance. 

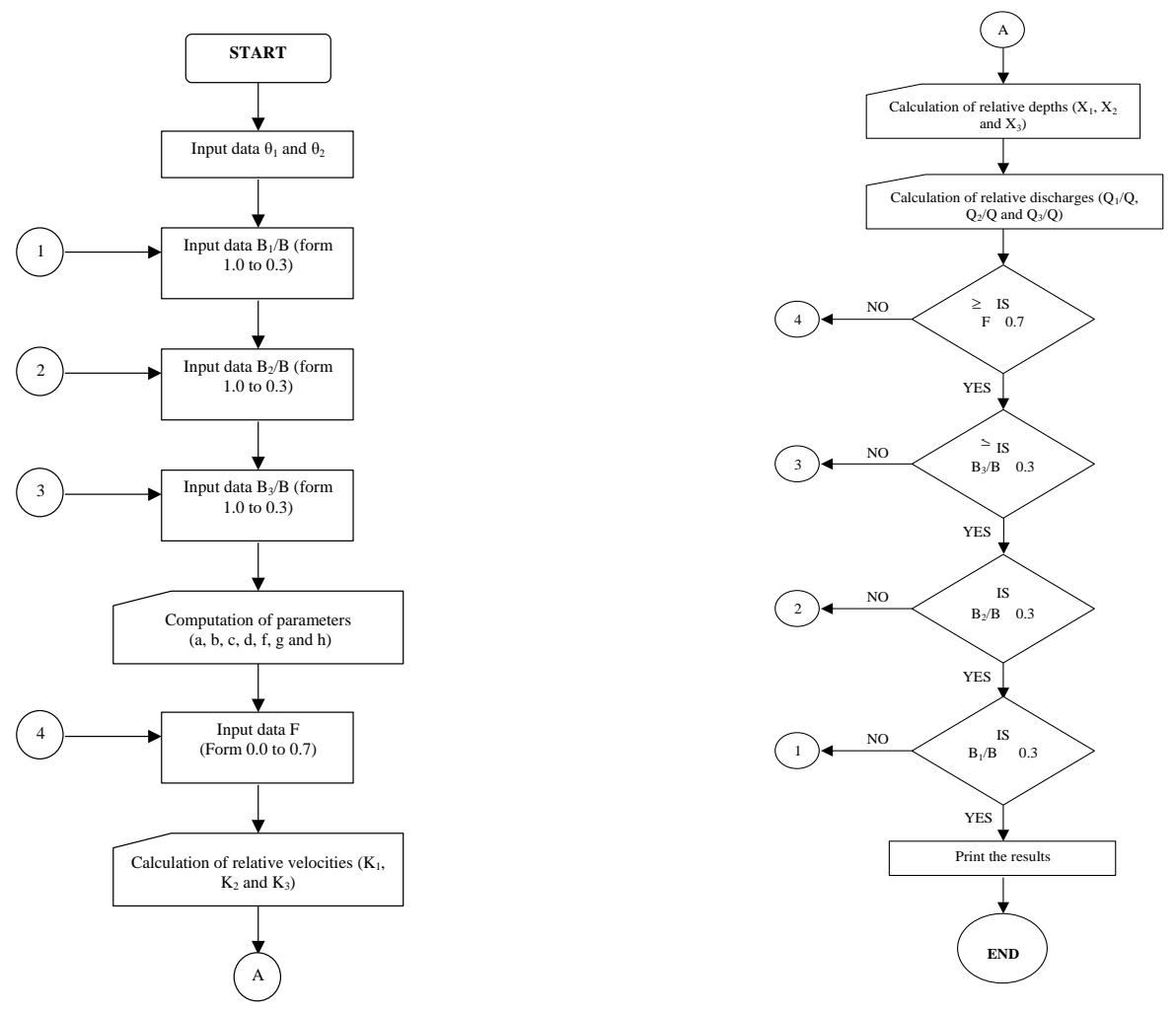

Fig (2) Flow chart of the computer program

Figure (3) gives a general view of the experimental setup. The intersection angles were varied to take $90^{\circ}, 60^{\circ}$ and $30^{\circ}$ for each. Water depths in branched channels were controlled to be same as in the numerical model by means of vertical gates located at the end of each and were measured using point gauges. To avoid the backwater effect and flow disturbances, the mean depth of each channel was taken at a station $1.2 \mathrm{~m}$ from the center of the junction [2]. The inflow rates were regulated by a gate valve and were measured by a calibrated flow meter. The branched channels flow rates were measured volumetrically. The total inlet flow rates were ranged from 3.0 liters/sec to 15 liters/sec.

Model Verification: A series of laboratory tests was performed on the dividing flow at horizontal channel junction having three tributary branches for different junction angles and different relative branches bed width. Water depths in the experiments were taken to be same as in the numerical model and the corresponding discharges were measured. Figure (4) shows the plotting of the experimental mean relative discharge values $\left(\mathrm{Q}_{1} / \mathrm{Q}\right)_{\text {meas }},\left(\mathrm{Q}_{2} / \mathrm{Q}\right)_{\text {meas }}$ and $\left(\mathrm{Q}_{3} / \mathrm{Q}\right)_{\text {meas. }}$ versus the mean relative discharge values $\left(\mathrm{Q}_{1} / \mathrm{Q}\right)_{\text {num }},\left(\mathrm{Q}_{2} / \mathrm{Q}\right)_{\text {num. }}$ and $\left(\mathrm{Q}_{3} / \mathrm{Q}\right)_{\text {num. }}$ predicted from the numerical solution. A well agreement between the experimental and the numerical results is noticeable, especially for low discharges. The deviation between the results at high 
discharges may due to the formation of high turbulence at the junction in the experiments produces energy losses, while these losses of energy are neglected in numerical solution.

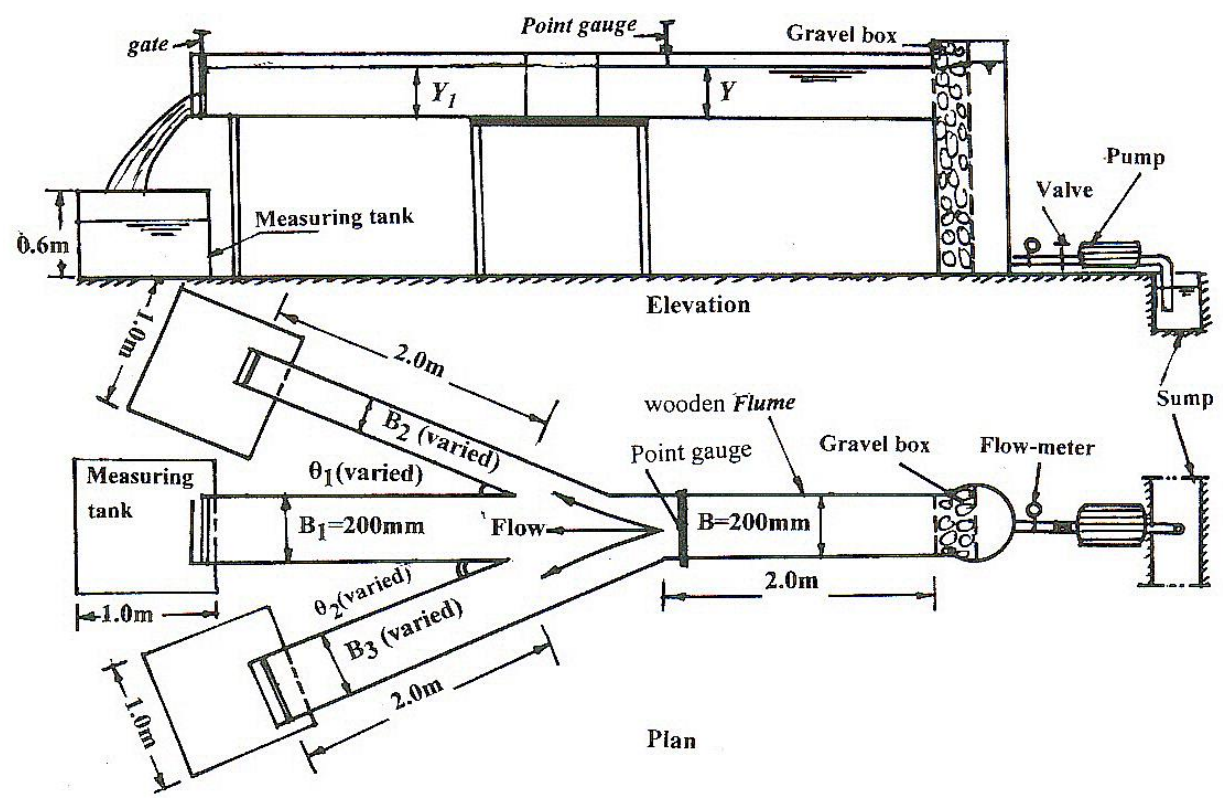

Fig. (3) Experimental setup.

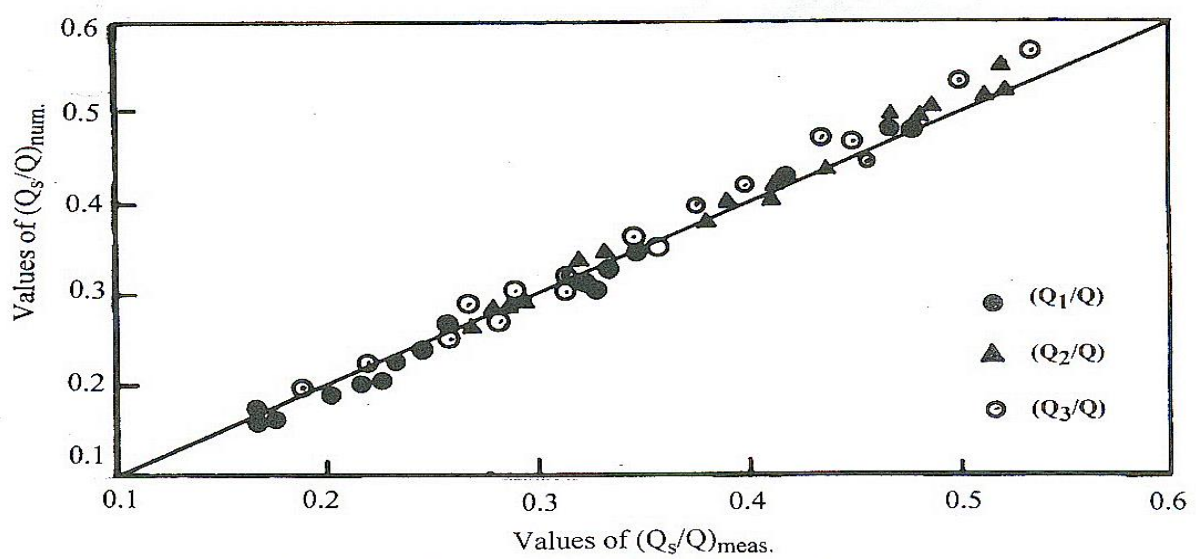

Fig. (4) Numerical results of the mean relative discharges $\left(Q_{S} / Q\right)_{\text {num }}$ versus the experimental ones $\left(\mathrm{Q}_{\mathrm{s}} / \mathrm{Q}\right)_{\text {meas }}(\mathrm{s}=1,2,3)$

\section{ANALYSIS OF THE NUMERICAL RESULTS AND DISCUSSIONS}

Relative Discharge in The Tributary Channels: The values of Froude number in the main channel, $F$ were drawn versus the relative discharge in branch channels $Q_{1} / Q$ and $\mathrm{Q}_{3} / \mathrm{Q}$ for different junction angles and relative widths of the branch channels. An 
example is shown in Fig. (5). It is obviously that the discharge in the branch channels is independent of the main channel Froude number.

Figures (6 and 7) show the variation of mean relative discharge $Q_{1} / Q$ and $Q_{3} / Q$ with the relative width $B_{3} / B$ and $B_{2} / B$ as a third variable at $B_{1} / B=1.0, \theta_{1}=90^{\circ}$ and $\theta_{2}$ $=90^{\circ}$ and $30^{\circ}$ respectively The relative discharge $\mathrm{Q}_{3} / \mathrm{Q}$ increases with the increase of ratio $B_{3} / B$, consequently $Q_{1} / Q$ values are decreasing by different percent according to $B_{2} / B$ ratios. For constant value of $\theta_{1}$ and $B_{1} / B$, the decrease of $\theta_{2}$ from $90^{\circ}$ to $30^{\circ}$ decreases the discharge ratio $\mathrm{Q}_{3} / \mathrm{Q}$ by about $29.5 \%$ and increases the relative discharge ratio $\mathrm{Q}_{1} / \mathrm{Q}$ by about $20 \%$. Also, the relative discharge ratio $\mathrm{Q}_{2} / \mathrm{Q}$ in the second branch of width $B_{2}$ is obtained from the continuity equation as: $Q_{2} / Q=1-\left(Q_{1} / Q+Q_{3} / Q\right)$.

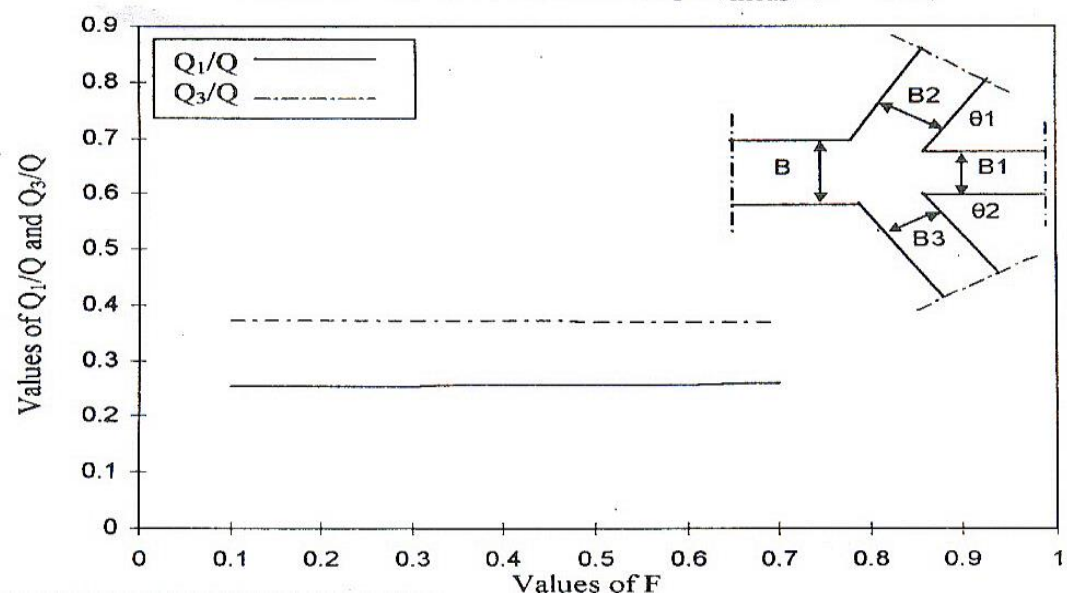

Fig. 5 Variation of $\mathrm{Q}_{1} / \mathrm{Q}$ and $\mathrm{Q}_{3} / \mathrm{Q}$ versus $\mathrm{F}$ at

$\left(\mathrm{B}_{1} / \mathrm{B}=\mathrm{B}_{2} / \mathrm{B}=\mathrm{B}_{3} / \mathrm{B}=1\right.$ and $\left.\theta_{1}=\theta_{2}=60^{\circ}\right)$

To study the effect of varying the ratio $\mathrm{B}_{1} / \mathrm{B}$ on the dividing discharges at the junction, the values of $\theta_{1}$ and $\theta_{2}$ are kept constants at $60^{\circ}$ and the numerical results of $\mathrm{B}_{3} / \mathrm{B}$ and both $\mathrm{Q}_{1} / \mathrm{Q}$ and $\mathrm{Q}_{3} / \mathrm{Q}$ are plotted in Figs. (8 to 10 ). The values of $\mathrm{B}_{2} / \mathrm{B}$ are changed to take values between 0.3 and 1.0 and plotted as a third dimension in all the figures. The same trend of the results is seen, where the values of $Q_{1} / Q$ decrease with increasing of $\mathrm{B}_{3} / \mathrm{B}$.

For constant value of $B_{3} / B$ the increase of $B_{2} / B$ decreases the values of $Q_{1} / Q$. It is noticed from Figures that the rate of decreasing $Q_{1} / Q$ with the change $B_{2} / B$ is decreased with the decrease of $B_{1} / B$ till it becomes unreliable or ineffective on $Q_{1} / Q$ when $\mathrm{B}_{1} / \mathrm{B}$ is equal or less than 0.4 Also, from these Figures, it is noticeable that the decrease of relative width $B_{1} / B$ from 1.0 to 0.3 decreases the relative discharge $Q_{1} / Q$ by $79 \%$ and increases $Q_{3} / Q$ by $78 \%$, and the effect of $B_{3} / B$ on $Q_{3} / Q$ decrease with the decrease of $B_{1} / B$. For the influence of $B_{2} / B$ on both relative discharges $Q_{1} / Q$ and $Q_{3} / Q_{\text {, }}$ the results show that the decreasing of $B_{2} / B$ from 1.0 to 0.3 increases $Q_{1} / Q$ by $87 \%$ and $\mathrm{Q}_{3} / \mathrm{Q}$ by $22 \%$. Also, the increase of the relative width $\mathrm{B}_{3} / \mathrm{B}$ from 0.3 to 1.0 decreases $\mathrm{Q}_{1} / \mathrm{Q}$ by $48 \%$ and increases $\mathrm{Q}_{3} / \mathrm{Q}$ by about $22 \%$. 


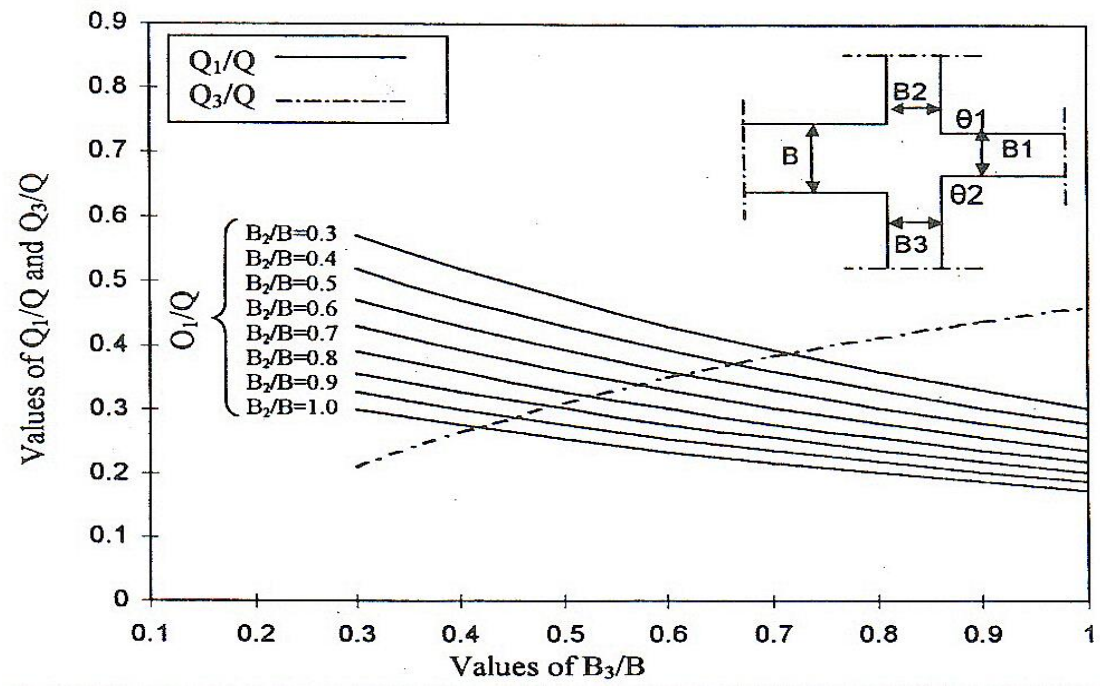

Fig. 6 Variation of $Q_{1} / Q$ and $Q_{3} / Q$ versus $B_{3} / B$ for various values of $B_{2} / B$ at $\left(\mathrm{B} ! / \mathrm{B}=1\right.$ and $\left.\theta_{1}=\theta_{2}=90^{\circ}\right)$

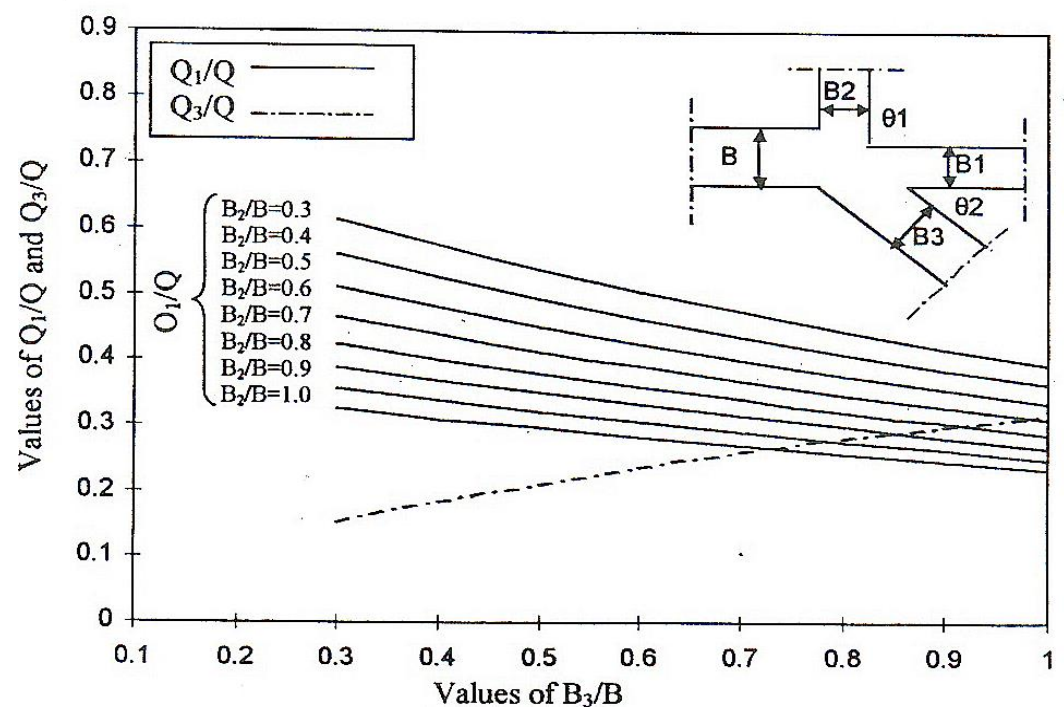

Fig. 7 Variation of $Q_{1} / Q$ and $Q_{3} / Q$ versus $B_{3} / B$ for various values of $B_{2} / B$ at $\left(\mathrm{B}_{1} / \mathrm{B}=1\right.$ and $\theta_{1}=90^{\circ}$ and $\left.\theta_{2}=30^{\circ}\right)$ 


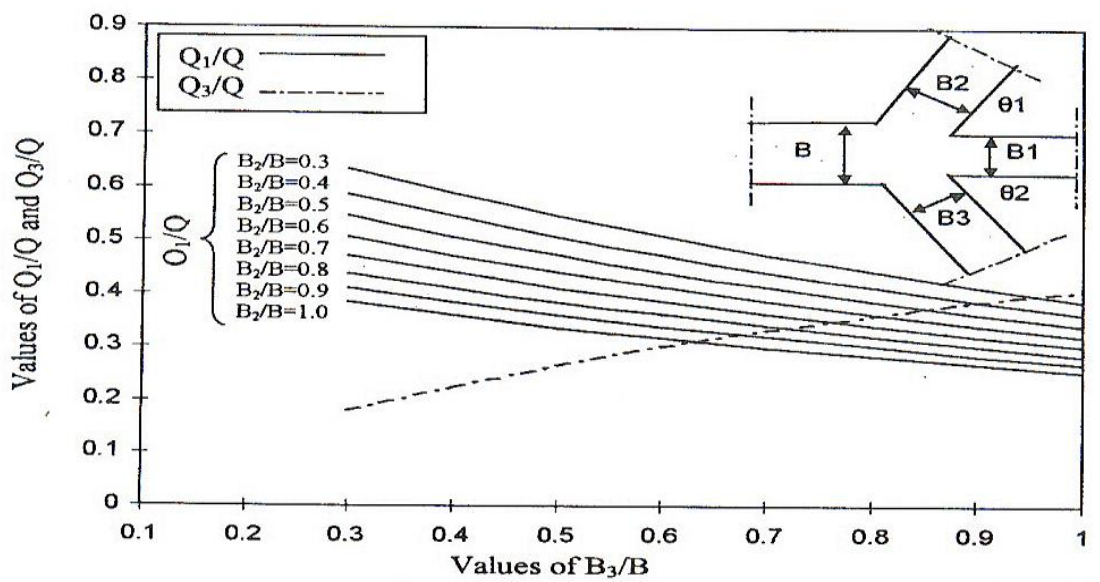

Fig. 8 Variation of $\mathrm{Q}_{1} / \mathrm{Q}$ and $\mathrm{Q}_{3} / \mathrm{Q}$ versus $\mathrm{B}_{3} / \mathrm{B}$ for various values

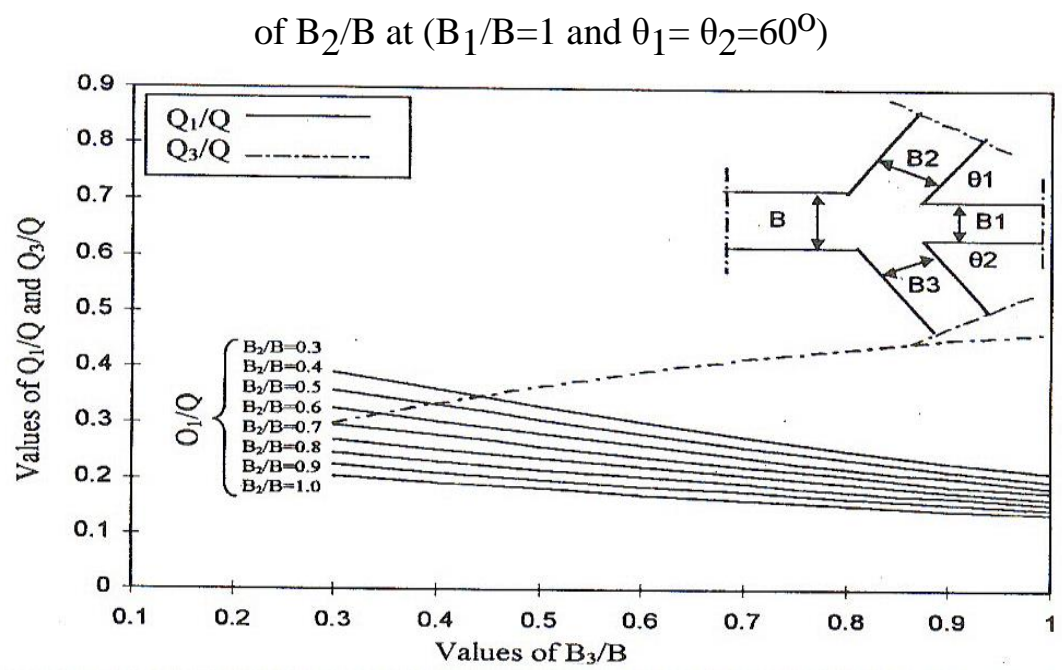

Fig. 9 Variation of $Q_{1} / Q$ and $Q_{3} / Q$ versus $B_{3} / B$ for various values

$$
\text { of } B_{2} / B \text { at }\left(B_{1} / B=0.6 \text { and } \theta_{1}=\theta_{2}=60^{\circ}\right)
$$

Froude Numbers in The Tributary Channels: Froude number may represent the flow characteristics either in the main channel extension or in the tributary channels. The numerical results (as example) are plotted in Figs. (11 and 14) to illustrate the variation of Froude numbers in the tributary channels $\left(F_{1}, F_{2}\right.$, and $\left.F_{3}\right)$ with Froude number in the main channel $(F)$ for various values of $\theta_{1}$ and $\theta_{2}$, at a range of $B_{3} / B$ from 0.3 to 1.0 with different values of $B_{1} / B$ and $B_{2} / B$. Values of Froude number in the tributary channels $\left(\mathrm{F}_{1}, \mathrm{~F}_{2}\right.$ and $\left.\mathrm{F}_{3}\right)$ increase with the increase of the value of Froude number in the main channel $F . F_{1}$ and $F_{3}$ are dependent on the width ratio $B_{3} / B$ while the values of $F_{2}$ is independent of the width ratio $B_{3} / B$. The rate of increasing $F_{3}$ with decreasing $B_{3} / B$ decreases with the decrease of $\theta_{2}$, while $F_{1}$ values are decreased with the decrease of $\theta_{1}$. 


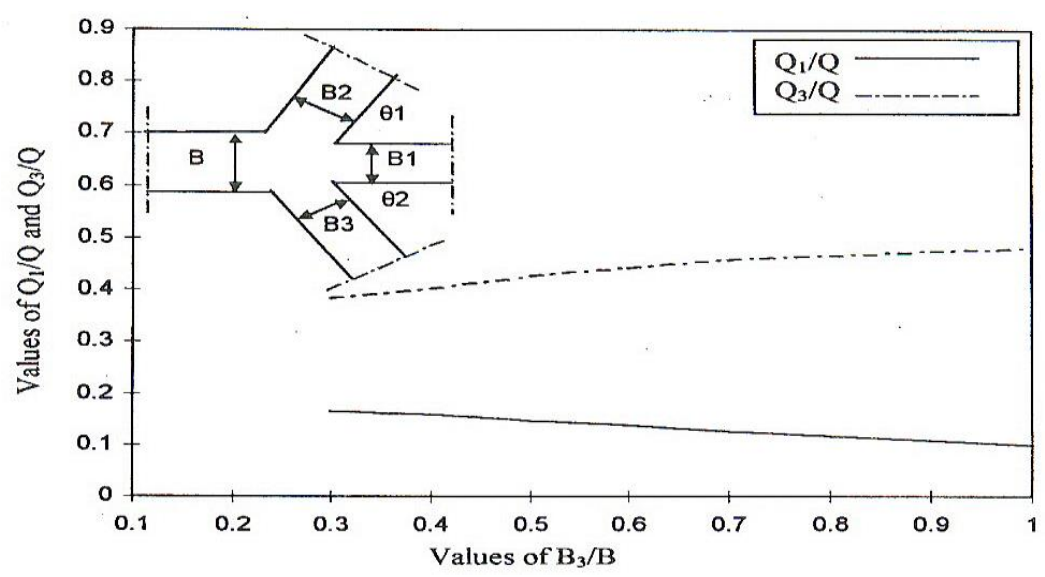

Fig. 10: Variation of $Q_{1} / Q$ and $Q_{3} / Q$ versus $B_{3} / B$ for various values of $\mathrm{B}_{2} / \mathrm{B}$ at $\left(\mathrm{B}_{1} / \mathrm{B}=0.4\right.$ and $\left.\theta_{1}=\theta_{2}=60^{\circ}\right)$

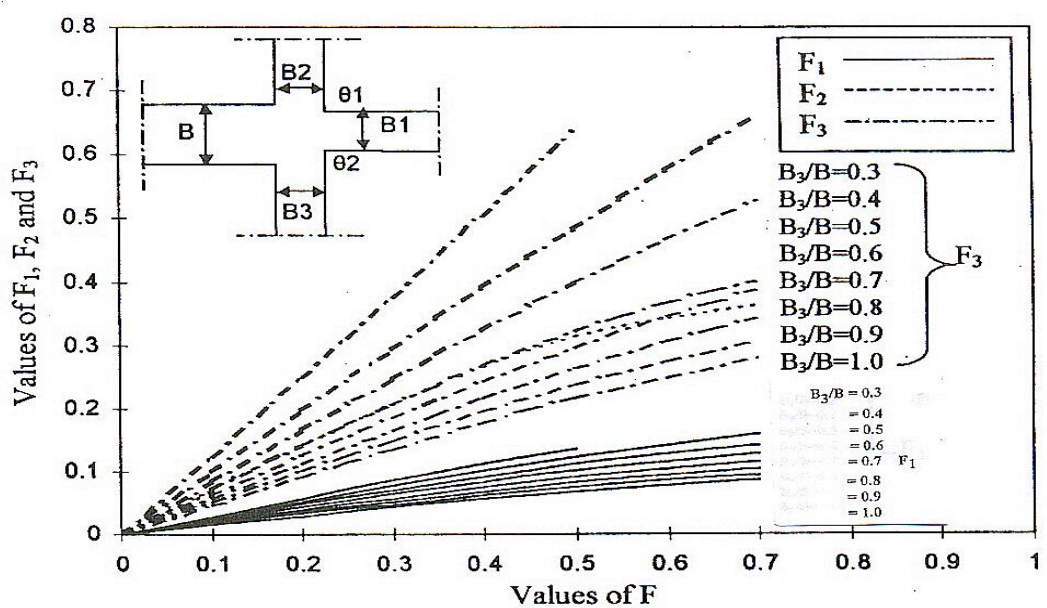

Fig. 11 Variation of $F_{1}, F_{2}$ and $F_{3}$ versus $F$ for different values

$$
\text { of } B_{3} / B \text { at }\left(B_{1} / B=B_{2} / B=0.6 \text { and } \theta_{1}=\theta_{2}=90^{\circ}\right)
$$

The relations show also, that the rate of the increase of $\mathrm{F}_{3}$ with $\mathrm{B}_{3} / \mathrm{B}$ decreases with the decrease of $\theta_{2}$ values. Also these figures indicate that, for constant values of $\theta_{1}, B_{1} / B$ and $B_{2} / B$ the rate of increasing, $F_{1}$ with $F$ is increasing but the rate of increasing $F_{3}$ with $F$ is decreasing. For example when $\theta_{2}=90^{\circ}, F_{1}$ varies from 0.0171 to 0.0192 while for $\theta_{2}=30^{\circ}, F_{1}$ varies from 0.0227 to 0.125 . Also, for $\theta_{2}=90^{\circ}, F_{3}$ varies from 0.04 to 0.2139 while for $\theta_{2}=30^{\circ}, F_{3}$ varies from 0.0246 to 0.1364 .

The relative width $\mathrm{B}_{1} / \mathrm{B}$ of the main channel extension is an important parameter for defining the state of flow in the tributary channels. The following example illustrates this fact quite well. When $\theta_{1}=90^{\circ}, \theta_{2}=30^{\circ}, \mathrm{B}_{2} / \mathrm{B}$ and $\mathrm{B}_{3} / \mathrm{B}=1.0$ and $\mathrm{F}$ varies in range from 0.1 to 0.7 , at $\mathrm{B}_{1} / \mathrm{B}=1.0, \mathrm{~F}_{1}$ varies from 0.0241 to 0.1324 , while at $\mathrm{B}_{1} / \mathrm{B}=0.6, \mathrm{~F}_{1}$ varies from 0.0126 to 0.0716 . So, the influence of relative width $\mathrm{B}_{1} / \mathrm{B}$ on the Froude number in the extension of the main channel $F_{1}$ is noticed, where by decreasing $\mathrm{B}_{1} / \mathrm{B}$ from 1.0 to $0.6, \mathrm{~F}_{1}$ decreases by about $50 \%$. Also, in these Figures, the 
influence of the relative width of the extension of the main channel $\mathrm{B}_{1} / \mathrm{B}$ on Froude number of the second branch channel $F_{2}$ is clearly shown, while $F_{2}$ is shown independent of the values of $B_{3} / B$. The rate of increasing $F_{2}$ with $B_{1} / B$ is constant.

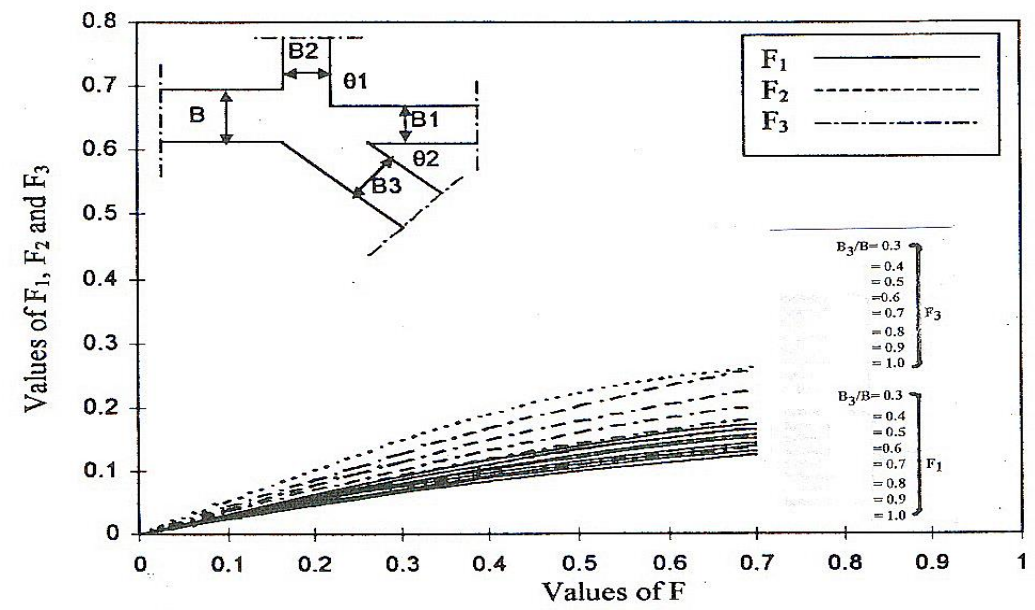

Fig. 12 Variation of $\mathrm{F}_{1}, \mathrm{~F}_{2}$ and $\mathrm{F}_{3}$ versus $\mathrm{F}$ for different values of $\mathrm{B}_{3} / \mathrm{B}$ at $\left(\mathrm{B}_{1} / \mathrm{B}=\mathrm{B}_{2} / \mathrm{B}=1.0\right.$ and $\left.\theta_{1}=90^{\circ} \theta_{2}=30^{\circ}\right)$

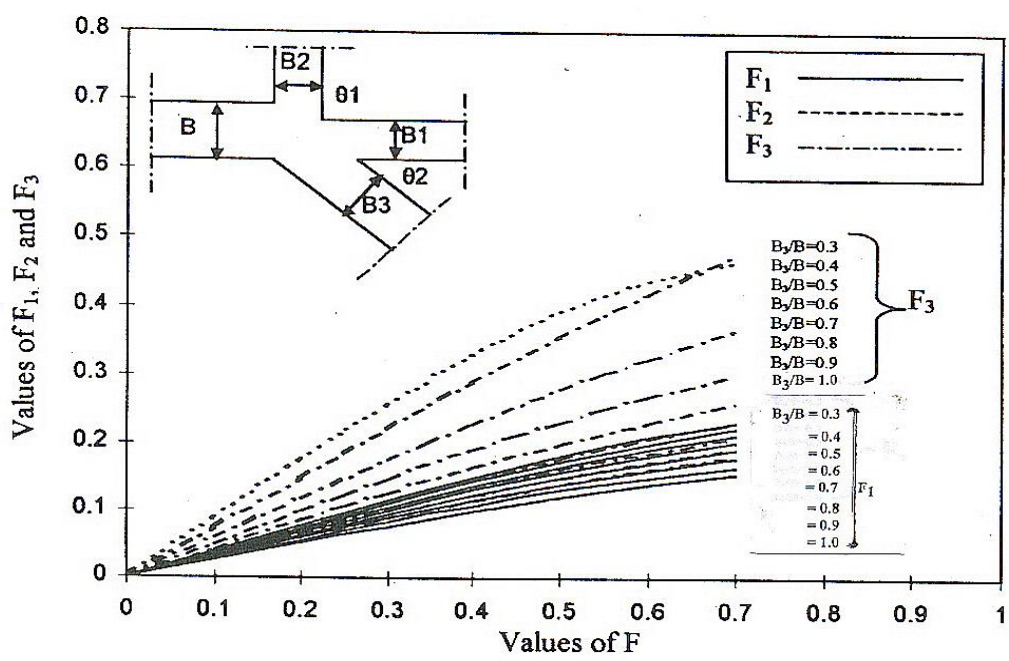

Fig. 13 Variation of $F_{1}, F_{2}$ and $F_{3}$ versus $F$ for different values of $\mathrm{B}_{3} / \mathrm{B}$ at $\left(\mathrm{B}_{1} / \mathrm{B}=\mathrm{B}_{2} / \mathrm{B}=0.6\right.$ and $\left.\theta_{1}=90^{\circ} \theta_{2}=30^{\circ}\right)$ 


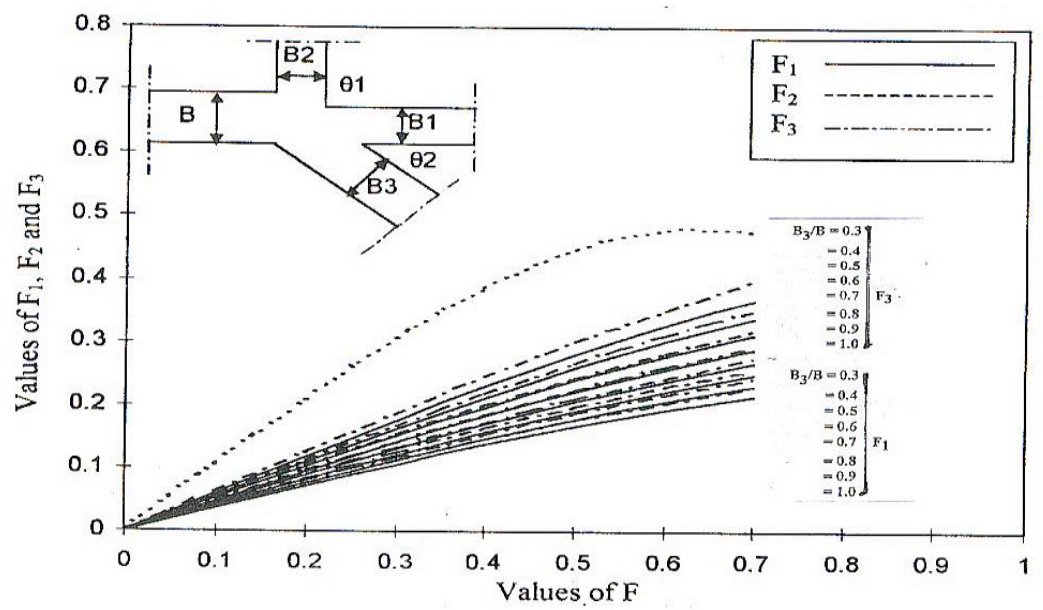

Fig. 14 Variation of $F_{1}, F_{2}$ and $F_{3}$ versus $F$ for different values

$$
\text { of } \mathrm{B}_{3} / \mathrm{B} \text { at }\left(\mathrm{B}_{1} / \mathrm{B}=0.6, \mathrm{~B}_{2} / \mathrm{B}=0.3 \text { and } \theta_{1}=90^{\circ} \theta_{2}=30^{\circ}\right)
$$

The influence of the relative width of the main channel extension $B_{1} / B$ on $F_{3}$ is the same as $\mathrm{F}_{2}$ where by decreasing $\mathrm{B}_{1} / \mathrm{B}$ form 1.0 to 0.3 , $\left(\mathrm{F}_{2}\right)$ values increases by about $47 \%$. As we mentioned above that the relative width of the extension of the main channel $B_{1} / B$ has the same as $F_{2}$ and $F_{3}$, while the decreasing of $B_{1} / B$ from 1.0 to 0.3 , $\mathrm{F}_{3}$ increases by about $10 \%$. The width of the second branch channel $\mathrm{B}_{2} / \mathrm{B}$ is an important parameter that may define the state of flow of subcritical, critical or supercritical in the tributary channels. The comparison of data shown in Figs. (11 to 14) where $B_{2} / B$ changes from 1.0 to 0.3 illustrate this fact very well. Where by decreasing $B_{2} / B$, the values of $F_{1}$ are increasing. This can be verified as follows, when $\theta_{1}=90^{\circ}, \theta_{2}=30^{\circ}, B_{1} / B=0.6, B_{3} / B=0.7$ and $F$ varies in range from 0.1 to 0.7 for $B_{2} / B=1.0$, $\mathrm{F}_{1}$ varies from 0.0249 to 0.1380 , while for $\mathrm{B}_{2} / \mathrm{B}=0.3 \mathrm{~F}_{1}$ varies from 0.0447 to 0.2674 . So, by decreasing the relative width of the second branch $\mathrm{B}_{2} / \mathrm{B}$ from 1.0 to 0.3 Froude number in the extension of the main channel $\mathrm{F}_{1}$ increases by about $85 \%$. Also, it is seen that, $F_{2}$ increases by about $75 \%$ by decreasing $B_{2} / B$ from 1.0 to 0.3 , while $F_{3}$ increases by about $48 \%$ for the same trend of decreasing of $B_{2} / B$.

Relative depths in The Tributary Channels: The numerical results of the relative depth in the main channel extension $\left(\mathrm{Y}_{1} / \mathrm{Y}\right)$, and in the tributary channels $\left(\mathrm{Y}_{2} / \mathrm{Y}\right.$ and $\mathrm{Y}_{3} / \mathrm{Y}$ ) versus Froude number in the main channel, $\mathrm{F}$ are plotted in Figs. (15 to 17). The relative flow depths $\left(\mathrm{Y}_{1} / \mathrm{Y}, \mathrm{Y}_{2} / \mathrm{Y}\right.$ and $\left.\mathrm{Y}_{3} / \mathrm{Y}\right)$ increase with the increase of Froude number in the main channel. The increase of the Froude number in the main channel, $F$ from 0.0 to 0.7 , the relative flow depths in the tributary channels $\left(\mathrm{Y}_{1} / \mathrm{Y}, \mathrm{Y}_{2} / \mathrm{Y}\right.$ and $\left.\mathrm{Y}_{3} / \mathrm{Y}\right)$, increase by about $22 \%$. So, the main channel Froude number $(\mathrm{F})$ is considered very important parameter affecting the relative depths in the tributary channels $\left(\mathrm{Y}_{1} / \mathrm{Y}\right.$, $\mathrm{Y}_{2} / \mathrm{Y}$ and $\left.\mathrm{Y}_{3} / \mathrm{Y}\right)$.

The influence of the angles of intersection at the junction $\left(\theta_{1}\right.$ and $\left.\theta_{2}\right)$ on the relative depths in tributary channels $\left(\mathrm{Y}_{1} / \mathrm{Y}, \mathrm{Y}_{2} / \mathrm{Y}\right.$ and $\left.\mathrm{Y}_{3} / \mathrm{Y}\right)$ is also shown in Figures. From these Figures, it is clearly seen that the relative depth ratios independent on both $\theta_{1}$ and $\theta_{2}$, where the maximum difference in the calculated values of the tributary 
channels $\mathrm{Y}_{1} / \mathrm{Y}, \mathrm{Y}_{2} / \mathrm{Y}$ and $\mathrm{Y}_{3} / \mathrm{Y}$ with the variation of $\theta_{1}$ and $\theta_{2}$ from $90^{\circ}$ to $30^{\circ}$ is not exceeding $3 \%$. The variation of the relative widths of the tributary channels $\left(\mathrm{B}_{1} / \mathrm{B}\right.$, $\mathrm{B}_{2} / \mathrm{B}$ and $\left.\mathrm{B}_{2} / \mathrm{B}\right)$ with the relative depths $\left(\mathrm{Y}_{1} / \mathrm{Y}, \mathrm{Y}_{2} / \mathrm{Y}\right.$ and $\left.\mathrm{Y}_{3} / \mathrm{Y}\right)$ for $\theta_{1}=90^{\circ}, \theta_{2}=30^{\circ}$ are shown also in Figs. (15 to 17). The relative flow depths in the tributary channels have slightly changes. So we can say that the relative depth ratios $\left(\mathrm{Y}_{1} / \mathrm{Y}, \mathrm{Y}_{2} / \mathrm{Y}\right.$ and $\left.\mathrm{Y}_{3} / \mathrm{Y}\right)$ are independent on the relative width ratios $\left(\mathrm{B}_{1} / \mathrm{B}, \mathrm{B}_{2} / \mathrm{B}\right.$ and $\left.\mathrm{B}_{3} / \mathrm{B}\right)$.

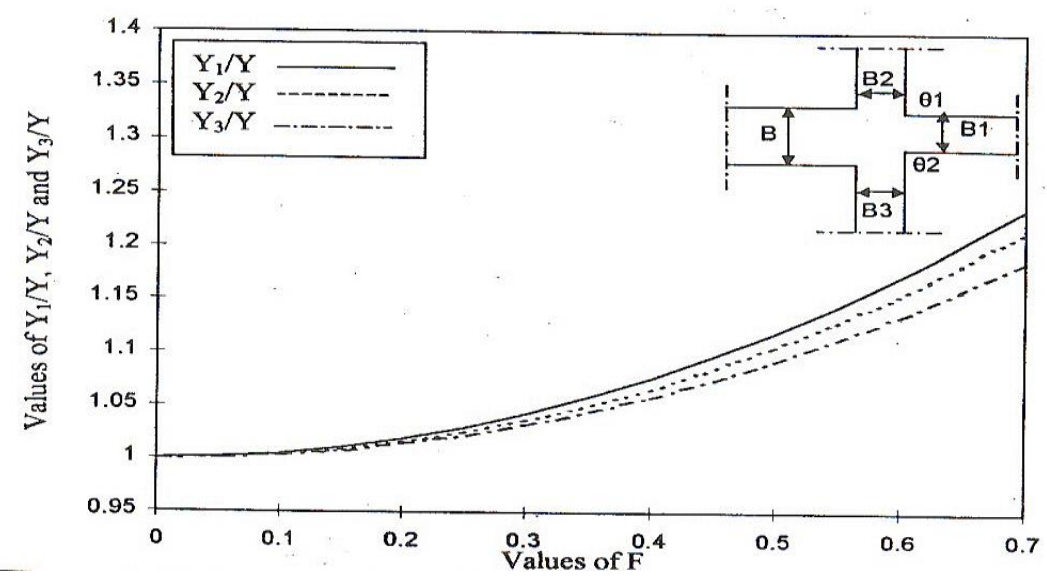

Fig. 15 Variation of $\mathrm{Y}_{1} / \mathrm{Y}, \mathrm{Y}_{2} / \mathrm{Y}$ and $\mathrm{Y}_{3} / \mathrm{Y}$ versus $\mathrm{F}$ for

$$
\left(B_{1} / B=B_{2} / B=1.0 \text { and } \theta_{1}=\theta_{2}=90^{\circ}\right)
$$

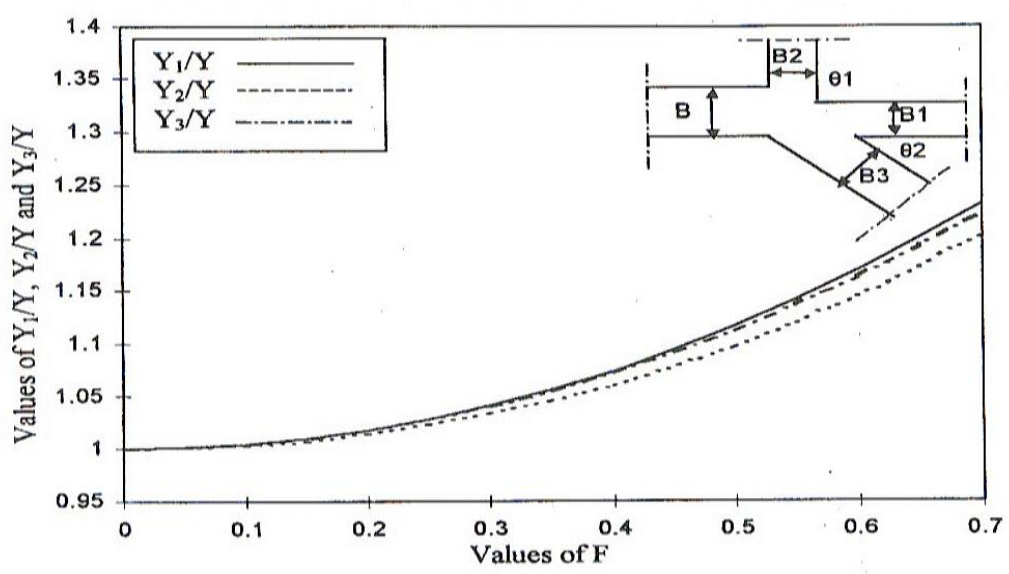

Fig. 16 Variation of $\mathrm{Y}_{1} / \mathrm{Y}, \mathrm{Y}_{2} / \mathrm{Y}$ and $\mathrm{Y}_{3} / \mathrm{Y}$ versus $\mathrm{F}$ for

$$
\left(\mathrm{B}_{1} / \mathrm{B}=\mathrm{B}_{2} / \mathrm{B}=1.0, \theta_{1}=90^{\circ} \text { and } \theta_{2}=30^{\circ}\right)
$$




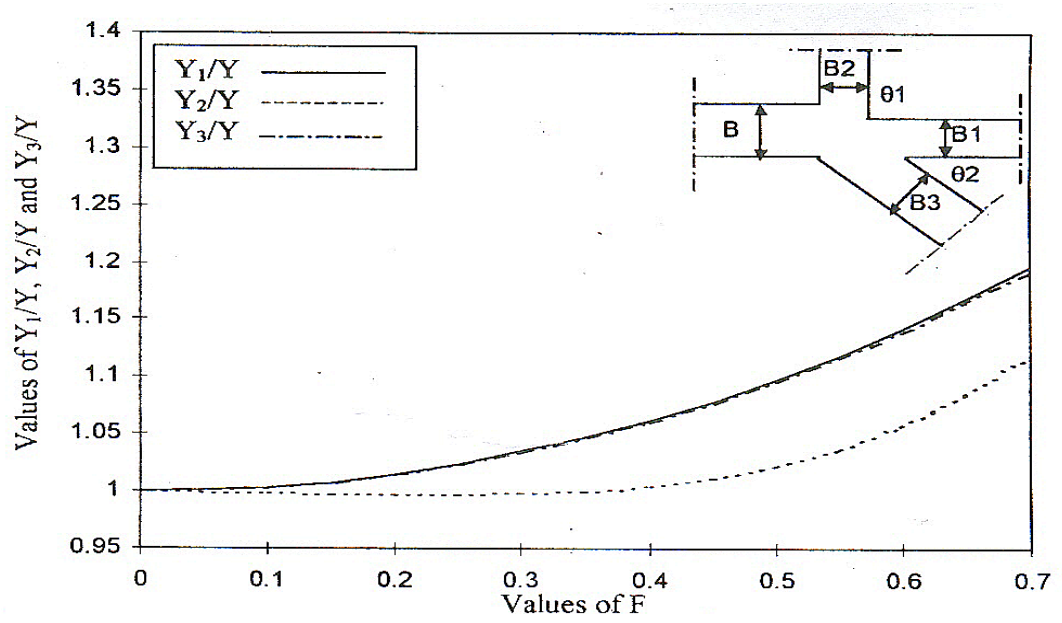

Fig. 17 Variation of $\mathrm{Y}_{1} / \mathrm{Y}, \mathrm{Y}_{2} / \mathrm{Y}$ and $\mathrm{Y}_{3} / \mathrm{Y}$ versus $\mathrm{F}$ for

$$
\left(\mathrm{B}_{1} / \mathrm{B}=0.8, \mathrm{~B}_{2} / \mathrm{B}=0.3, \theta_{1}=90^{\circ} \text { and } \theta_{2}=30^{\circ}\right)
$$

\section{CONCLUSIONS}

A numerical solution for the problem of dividing flow at open channel junction has been obtained. Such a numerical model presents quantitative conclusion, which could be helpful in developing insight about flow behavior at open channel junction. From the presented model and for sub-critical flow in main channel, the following conclusions may be drawn:

1- The flow rates either in the main channel extension or in the branch channels depend largely on the geometric dimensions of the junction [angles of intersection at the junction $\left(\theta_{1}\right.$ and $\left.\theta_{2}\right)$ and relative width of tributary channels].

2- Froude number in main channel has negligible influence on flow rates in the branches.

3- The flow characteristic in the main channel extension as well as in the branched channels are dependent on the flow behavior in the main channel (represented by Froude number, F) and the geometric dimensions of the junction [angles of intersection at the junction $\left(\theta_{1}\right.$ and $\left.\theta_{2}\right)$ and relative width of tributary channels].

4- The relative flow depths in the tributary channels $\left(\mathrm{Y}_{1} / \mathrm{Y}, \mathrm{Y}_{2} / \mathrm{Y}\right.$ and $\left.\mathrm{Y}_{3} / \mathrm{Y}\right)$ depend on the flow characteristic of the flow in the main channel represented by Froude number and independent of the junction geometry.

\section{REFERENCES}

1- Taylor, E.H., "Flow characteristics at rectangular open channel junction", Trans., ASCE, Vol. 109 pp. 893- 902, Nov. 1944.

2- Neary, V.S., and Odgaard, J.A.," Three dimensional flow at open channel diversion", J. Hydr. Eng., ASCE, 119(11), Nov.1993.

3- Ali, N. A., "A theoretical study of dividing flow in an open channel junction", Bulletin of the Faculty of Eng., Assiut University Vol. 18, No. 2, 1990. 
4- Ali, N.A. and Gommah, E.E.,"Numerical analysis of potential flow segmentation at open channel diversion", Bulletin of the Faculty of Eng., Assiut University, 24 (2), 1996.

5- Greated, C. A., "A theoretical study of flow behavior at open channel junctions". Researches report No.6, University of Southampton, Department of Civil Engineering, England, Feb. 1964. (Cited from Ref. 13).

6- Hus, C.C, Wu, F.S, and Lee,W.J.," Flow at $90^{\circ}$ equal-width open channel junction", J. Hydr. Eng., ASCE, 124(2), pp. 186-191, Feb.1998.

7- Hassenpflug, W. C., "Branched channel free-streamlines", Comput. Meth. Appl. Mech. Engrg. 159 (3/4), pp.329-354, 1998.

8- Larry, J. W., Schumate, E. D., and Mawer. N., “ Experiments on flow at a $90^{\circ}$ openchannel junction”. Jour. of Hydr. Eng., ASCE, 127 (5), pp. 340-350, May 2001.

9- Law, S. W. and Reynolds, A. J., " Dividing flow in an open channel”, Jour. of Hyd. Div., ASCE, Vol., 92,No. HY3, pp. 207-230, 1966.

10- Modi, P. N., Ariel, P. D., and Dandekar, M. M. "Conformal mapping for channel junction flow”, Jour. Of Hyd. Div., ASCE, Vol. 107, No. HY12, Dec. 1981.

11- Rashwan, I.M.H.," Dynamic model for sub-critical dividing flow in open channel junction",Proc. Of $8^{\text {th }}$ Int. Water Tech. Conf.,IWTC, 2004, Alexandria, Egypt.

12- Webber, N. B., and Greated, C. A. "An investigation of flow behavior at the junction of rectangular channels." Proc., Instn. Of Civ. Engrs., Vol.34, Thomas Telford Ltd., London, pp. 321-334, 1966 (Cited from Ref. 8).

13- Yoshimi, Y. A. and Stelson, T. E., "Grit unbalance in sewage flow division", Jour. of sanitary Eng. Div., ASCE, Vol. 89, SA2, pp. 61- 82, 1953.

14- Sinha, S. K., and Odgaard, A. J., "Application of conformal mapping to diverging open channel flows”. Jour. of Engrg. Math. 30, pp. 355-363, 1996. (Cited from Ref. 7).

15- Milne-Thomson, "Theoretical Hydrodynamics", 5 ${ }^{\text {th }}$ Edition, Macmillan Press, 1979.

16- Chaung, J. M., Gui, Q. Y., and Hsiung, C. C., "Numerical computation of Schwarz- Christoffel transformation for simply connected unbounded domain", Comput. Meth. Appl. Mech. Engrg. 105, pp.93-109, 1993. (Cited from Ref. 18).

17- Gribnyak, S. T., Logvinenko, A. V., Romanenko, V. N., Fedorovich, A. Y., and Ennan, A. A., "Numerical investigation of the 2-dimensional potential flow of an ideal fluid using the Schwarz-Christoffel integral", Compt. Maths. Phys. 31 (8), pp.74-79, 1991. (Cited from Ref. 18)

18- Trevelyan, P. M. J., Illiot, L., and Ingham, D. B., "Potential flow in a finite channel with multiple sub-channels using the Schwarz-Christoffel transformation", Comp. Meth. Appl. Engrg. 189, pp. 341-359, 2000.

19- Kantorovich, L. V., and Krylov, V. I., "Approximate Methods of Higher Analysis”, Interscience, Noordhoff, pp. 521-542, 1958. (Cited from Ref. 18).

20- Trefethen, L. N., "Numerical computation of the Schwarz- Christoffel transformation”, SIAM J. Sci. Stat. Comput. 1 (1), pp. 82-102, 1980. (Cited from Ref. 18).

21- Driscoll, T. A., "Algorithm 756: A MATLAB toolbox for Schwarz- Christoffel mapping”, ACM Trans. Math. Softw. 22 (2), pp.168-186, 1996. 


\section{التحليل الرياضي و المعملي لتقسيم السريان في تفريعات القتوات المكثوفة ذات المدى القصير}

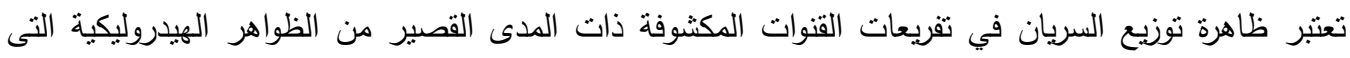

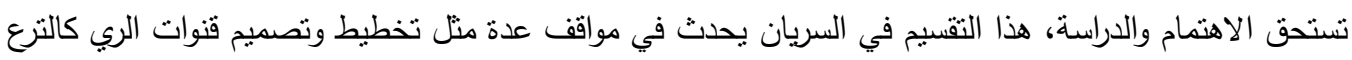

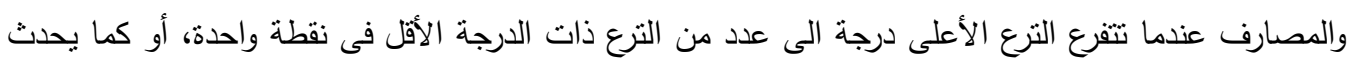

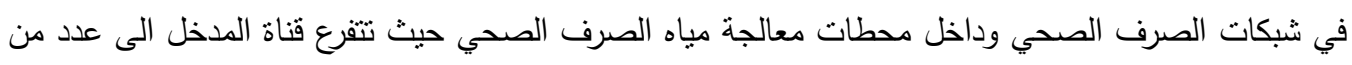

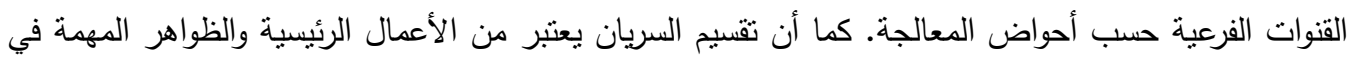
أعمال ومنشآت التحكم في مياه الري.

يقدم هذا البحث دراسة تحليلية رياضية ومعملية لتقرع السريان ذاتيا داخل القنوات المكثوفة اعتمادا على الى

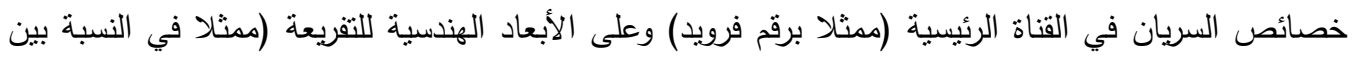

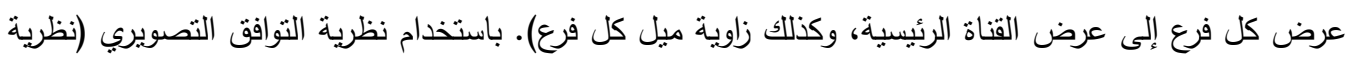

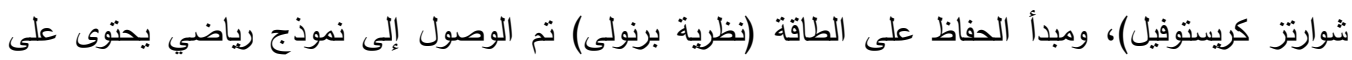

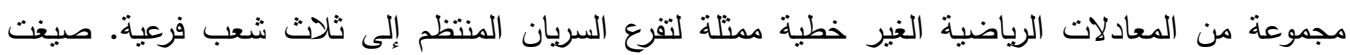

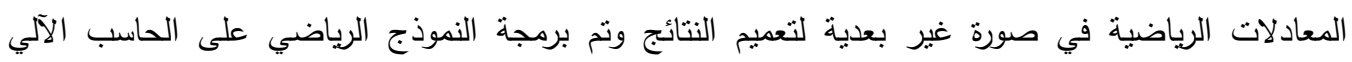

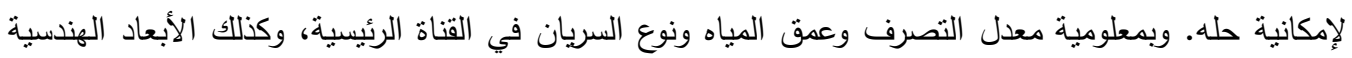

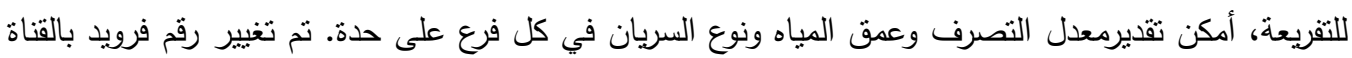

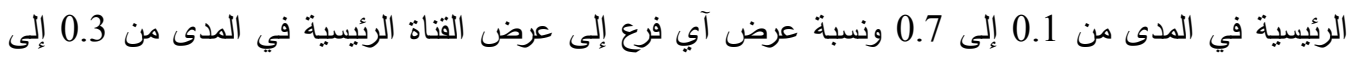

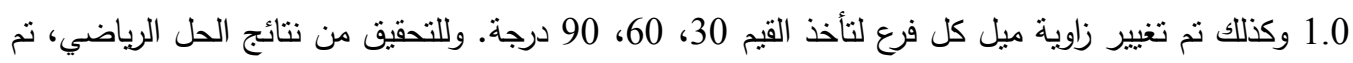

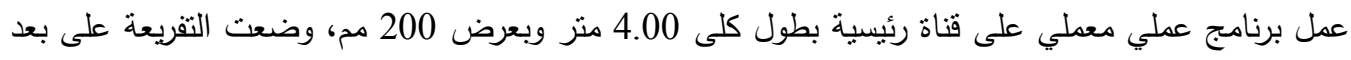

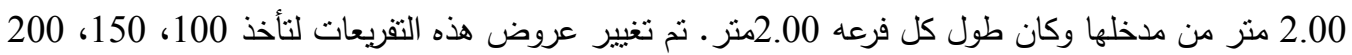

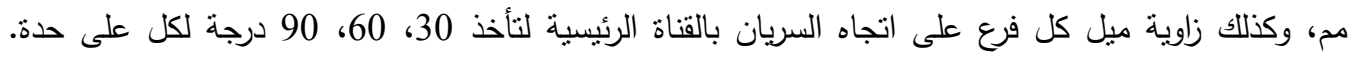

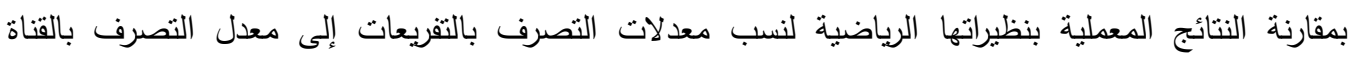

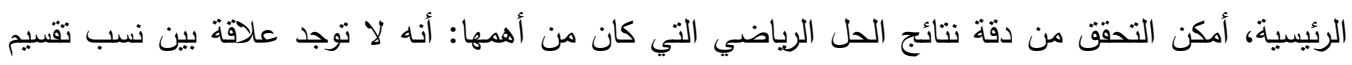

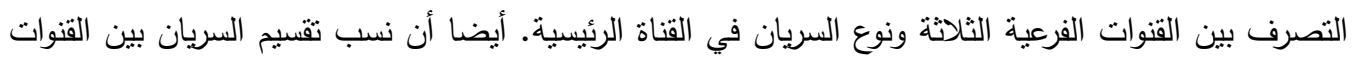

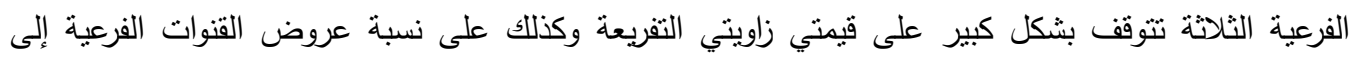

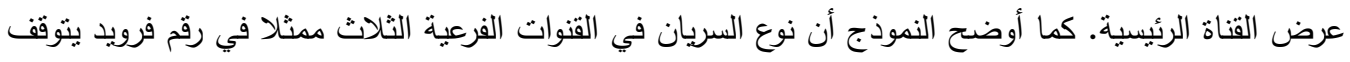

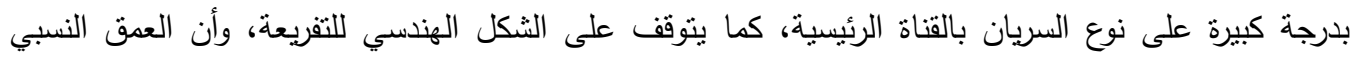
للسريان بالقنوات الفرعية الثناث لا يعتمد على الثنكل الهنسي للتفريعة. 